University of Nebraska - Lincoln

DigitalCommons@University of Nebraska - Lincoln

10-1977

\title{
Myxosoma funduli Kudo 1918 (Protozoa: Myxosporida) in Fundulus kansae: Summer Epizootiology
}

\author{
Stephen A. Knight \\ United States Department of Agriculture, Stephen.A.Knight@aphis.usda.gov \\ John J. Janovy Jr. \\ University of Nebraska - Lincoln, jjanovy1@unl.edu \\ William L. Current \\ Traganta Therapeutics
}

Follow this and additional works at: https://digitalcommons.unl.edu/bioscijanovy

Part of the Parasitology Commons

Knight, Stephen A.; Janovy, John J. Jr.; and Current, William L., "Myxosoma funduli Kudo 1918 (Protozoa: Myxosporida) in Fundulus kansae: Summer Epizootiology" (1977). John Janovy Publications. 38.

https://digitalcommons.unl.edu/bioscijanovy/38

This Article is brought to you for free and open access by the Papers in the Biological Sciences at DigitalCommons@University of Nebraska - Lincoln. It has been accepted for inclusion in John Janovy Publications by an authorized administrator of DigitalCommons@University of Nebraska - Lincoln. 


\title{
MYXOSOMA FUNDULI KUDO 1918 (PROTOZOA: MYXOSPORIDA) IN FUNDULUS KANSAE: SUMMER EPIZOOTIOLOGY
}

\author{
Stephen A. Knight, J. Janovy Jr., and W. L. Current \\ School of Life Sciences, University of Nebraska-Lincoln, Lincoln, Nebraska 68588
}

ABSTRACT: The occurrence and distribution of the myxosporidan Myxosoma funduli on the gills of the plains killifish (Fundulus kansae) were investigated; Fundulus kansae is reported as a new host. Host samples from various sites on the South Platte River, Nebraska, were collected during the summer months of 1975 and 1976. The protozoan parasite population was shown to be overdispersed within the host population, and this distribution was similar to that described by the negative binomial equation. Demographic characteristics of the infected fish subpopulation were virtually identical to those of the whole fish population. Infection intensity was independent of gill bar number or side. The frequency of bilateral infections was 0.54 , of left only infections was 0.23 , and of right only infections was 0.22 . Distribution of immature and mature plasmodia indicated that a pre-existing infection did not preclude a new infection, and suggested a prepatent period of less than two months.

Most previous studies of myxosporidan parasites have been taxonomic or have concerned the spread of infections in hatchery situations involving the transport of infected fish (Meyer, 1970; Sanders et al., 1970). This paper describes (1) the occurrence of a myxosporidan parasite, Myxosoma funduli Kudo 1918, in a population of Fundulus kansae (Garman) in their natural ecological setting, the South Platte River in Nebraska; (2) the distribution of $M$. funduli within the host fish population; and (3) observations that suggest features of the natural transmission mechanisms.

There is no detailed report of the life cycle of any protozoan parasite of the order Myxosporida. Although postulated life cycles have been published, little experimental transmission has been accomplished, and recent studies have suggested tissue phases for some species (Olsen, 1967; Hoffman and Putz, 1969, 1971; Hoffman and Hoffman, 1972). While discovery of factors regulating myxosporidan populations in nature must await discovery of life cycle details, studies such as the present one not only provide observations necessary for analysis of regulation mechanisms, regardless of the life cycle knowledge (Crofton, 1971; Pennycuick, 1971), but also suggest certain characteristics of transmission as it occurs in nature.

\section{MATERIALS AND METHODS}

Specimens of Fundulus kansae were collected by seining from the South Platte River in Keith

Received for publication 14 January 1977.
County, Nebraska, and taken immediately to the UN-L Cedar Point Biological Station 8 miles north of Ogallala, Nebraska. Samples from several sites within the county were obtained during the first year; however, differences in infection rates at the different sites were not significant when subjected to contingency table analysis, and so second year collections were restricted primarily to the Ogallala site.

A total of 538 fish were collected in 1975 (297) and 1976 (241). Fish from the first year's collection were measured (standard length), gills removed, and total plasmodia of right and left gills were counted under a dissecting microscope. Modifications of examination techniques were made following this initial study. The second year, fish were measured, sexed (gonad examination), and individual gill bars removed in sequence and examined under a compound microscope at $100 \times$ with a green filter. Plasmodia per gill bar were recorded and classified as "mature" or "immature" if they appeared or did not appear opaque respectively under these standard conditions. Both "immature" and "mature" plasmodia regularly contained spores, but "immature" plasmodia were often small enough to be missed with a dissecting microscope.

Efforts to fit plasmodia per fish data, for both 1975 and 1976, to the negative binomial distribution were made according to the methods of Pennycuick (1971).

Parasites were identified as Myxosoma funduli Kudo 1918, based on average measurements of 50 spores and host species. Spore shape, as well as length and width $(\bar{x}=13.75 \mu \mathrm{m}, \mathrm{SD}=0.61$; $\overline{\mathrm{x}}=8.63 \mu \mathrm{m}, \mathrm{SD}=0.58)$, polar capsule length and width $(\overline{\mathrm{x}}=8.29 \mu \mathrm{m}, \mathrm{SD}=0.62 ; \overline{\mathrm{x}}=2.21$ $\mu \mathrm{m}, \mathrm{SD}=0.42$ ), and numbers of spore wall striations $(\overline{\mathrm{x}}=6.08, \mathrm{SD}=1.24)$ were all consistent with the original description of $M$. funduli.

Host demography and aging estimates were analyzed and made according to the procedures of Minckley and Klaassen (1969), and size/age re- 


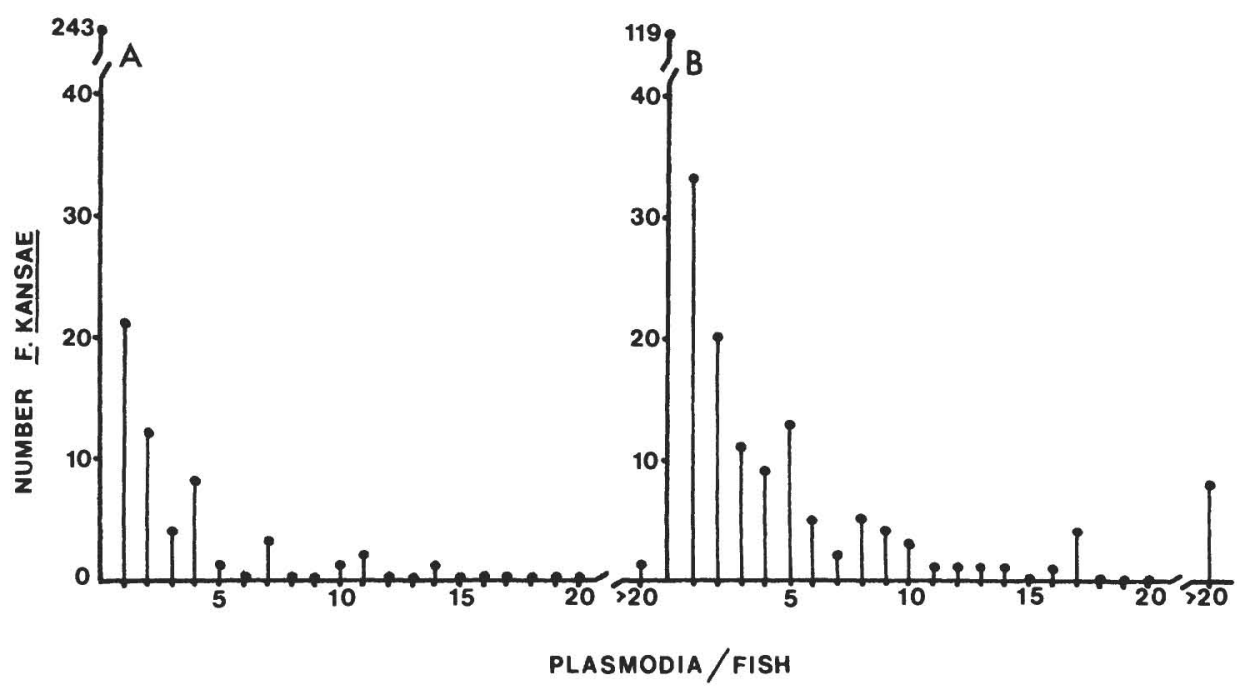

Figure 1. Frequency distributions of $M$. funduli plasmodia on the gills of $F$. kansae: A-Summer, 1975; B-Summer, 1976.

lationships used in this paper are based on their results and interpretations.

\section{The study area}

The South Platte River is that portion of the Platte River system west of North Platte, Nebraska. Proceeding downstream from the study area, the South Platte River converges with the North Platte River to form the Platte River. The South and the North Platte rivers differ both ecologically and in terms of their geological history. The South Platte River and the Platte River downstream from the point of confluence are typical braided plains rivers. The bed averages about a half mile across and is composed of coarse sand and gravel. During the summer, water depth rarely exceeds 18 inches except in "holes" around pilings and oxbows. The main channel, at Ogallala, is typically a maximum of $40 \mathrm{ft}$ across and tends to meander across the river bed. Discharge at the Colorado/Nebraska border ranges from amout $300 \mathrm{ft}^{3} / \mathrm{sec}$ to about $7,300 \mathrm{ft}^{3} / \mathrm{sec}$ but increases to 6,300 to $36,000 \mathrm{ft}^{3} / \mathrm{sec}$ at the eastern end of the state. The South Platte has a gradient of about $8.2 \mathrm{ft}$ per mile within Nebraska (Bentall, 1975). Late in summer, algal mats develop in shallows and isolated pools. This description generally fits the river at all collection sites. Collections were made in Keith County, Nebraska, at Big Springs, Brule, Ogallala, Roscoe, and Paxton in 1975, but only at Ogallala in 1976.

\section{RESULTS}

Figures 1A, B show the distribution of plasmodia within the sample host population, expressed as plasmodia per fish, for 1975 and 1976. The observed data for both years ap- peared overdispersed $(1975-\overline{\mathrm{x}}=0.6195, \mathrm{~s}=$ $2.142 ; 1976-\overline{\mathrm{x}}=3.784, \mathrm{~s}=10.58)$ and the distributions are similar to those generated by the negative binomial equation (Bliss, 1953). Attempts to fit the observations to the negative binomial resulted in the following parameter values: Fig. $1 \mathrm{~A}-\mathrm{k}=0.0613, \mathrm{R}=0.9099$, Fig. $1 \mathrm{~B}-\mathrm{k}=0.2338, \mathrm{R}=0.9418$. Chi-square goodness of fit tests $(\alpha=0.05)$ showed the 1976 data to fit the negative binomial; however, the 1975 data did not. This discrepancy is probably a result of inability to observe immature plasmodia through a dissecting microscope during the initial study.

Figures 2A, B, and 3 show demographic characteristics of both the total fish samples and for samples of the infected fish subpopulation. The mean sizes of collected fish and infected fish $( \pm S D)$ respectively were 6.57 $\mathrm{cm}$ (1.62) and $6.63 \mathrm{~cm}$ (2.16) for 1975, and $5.44 \mathrm{~cm} \mathrm{(2.46)}$ and $5.41 \mathrm{~cm} \mathrm{(1.93)} \mathrm{for} 1976$. There was little difference between the size distributions of infected fish and those of the total fish sample for either of the sampling periods. Differences in sample mean sizes between years, however, are interpreted as sampling bias, since smaller fish were simply not brought into the laboratory in large numbers in 1975, whereas in 1976 an effort was made to bring in all fish, regardless of size.

Figure 3 shows monthly size distributions 


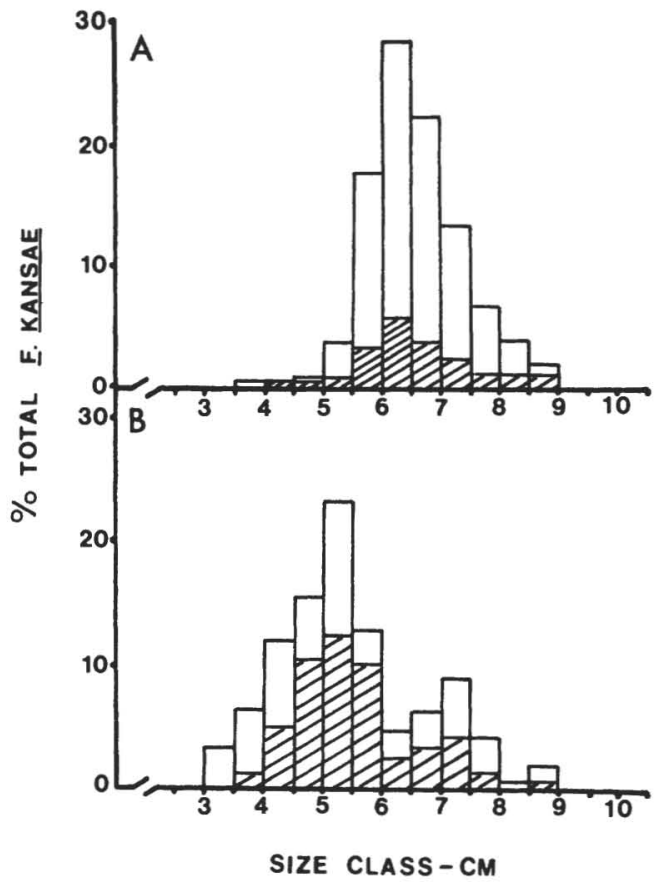

Figure 2. Size class distributions of total fish and infected fish subpopulations for two F. kansae samples: A-Summer, 1975; B-Summer, 1976. Open bars-Total fish sample. Cross-hatched bars -Infected fish subpopulation.

of total fish collected and of the infected subpopulation. A bimodal distribution in July reflects the growth of young of the year to the size which could be trapped in the quarter-inch seine. Although 3.5 to $4.0 \mathrm{~cm}$ fish are likely young of the year (Minckley and Klaassen, 1969), and infections in this size range were observed, no fish smaller than $3.5 \mathrm{~cm}$ was found to be infected. Thus, young of the year were infected but the smallest collected young of the year were not.

Figure 4 shows the composite percentage of infected fish vs. the various size classes of infected fish for 1976, and reveals that the most frequently infected fish were of a size suggesting oldest young of the year (4.5 to $6.0 \mathrm{~cm}$ ) or remaining second year fish (5.5 to $7.5 \mathrm{~cm}$ ).

Figure 5 shows the distribution of plasmodia on individual gill bars. Plasmodia distribution does appear somewhat unequal: bars \#2 and \#3 are shown to have more plasmodia than bars \#1 and \#4; however, contingency table analysis of these data indicated that plasmodial

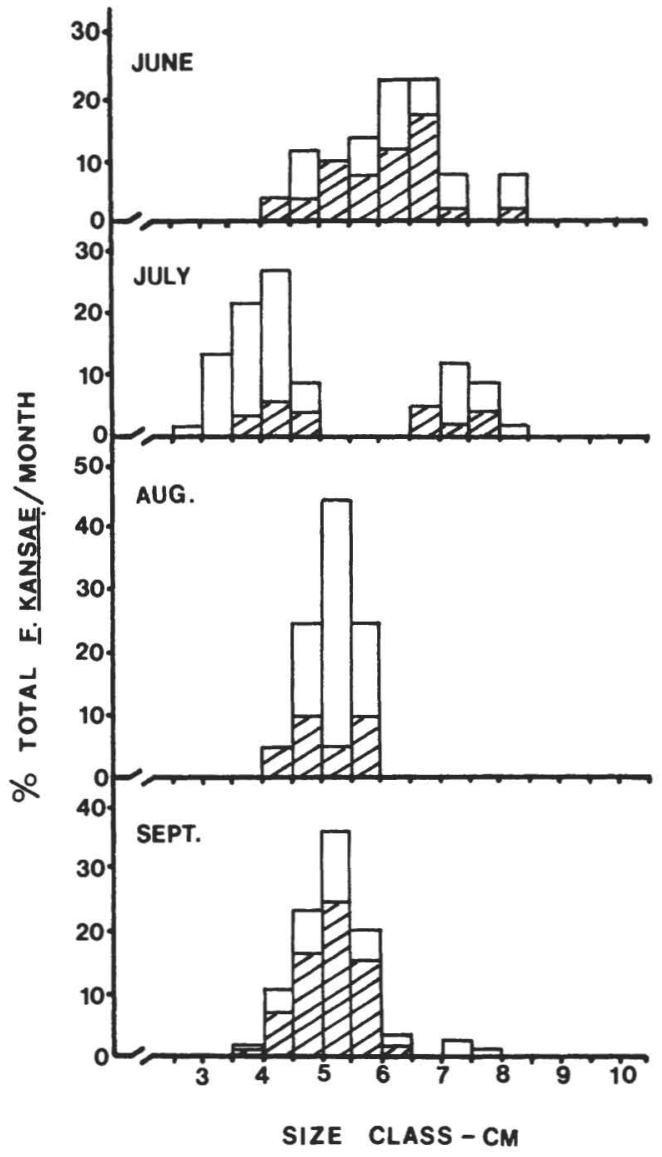

Figure 3. Monthly size class distributions of total fish and infected fish subpopulations for summer, 1976. Open bars-Total fish sample. Crosshatched bars-Infected fish subpopulation.

distribution is independent of gill bar number or side. Bars \# 1 and \#4 are somewhat smaller than \#2 and \#3, and this difference in size may account for the insignificant variation in infection intensity. Figure 5 also shows the percent infected gill bars of the total individual gill bars examined. Again the percent of infected individual gill bars appears unequal. Bars \#1 and \#4 are shown to be less frequently infected than bars \#2 and \#3 for both the right and left sides. However, contingency table analysis showed percent infection to be independent of gill bar, right or left.

The matter of unilateral vs. bilateral infections is of particular interest in that the frequency of bilateral infections was 0.54 , of right gill only infections was 0.22 , and of left gill only infections was 0.23 . Thus while the 


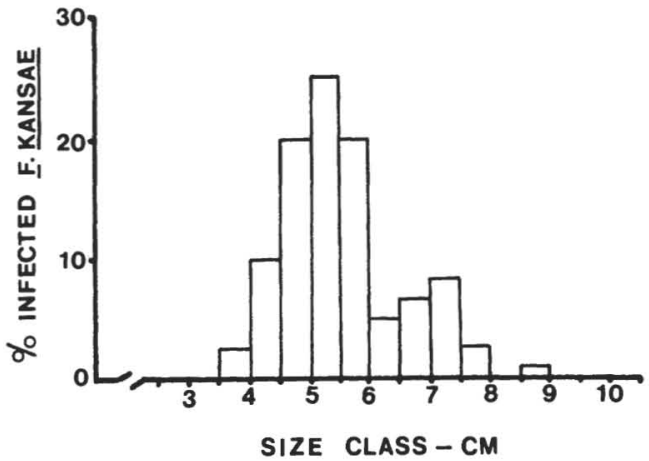

Figure 4. Size class distribution of infected fish subpopulation for summer, 1976.

probability of an infected fish being infected on the left side was virtually equal to the probability of a fish being infected on the right side, the probability of a bilateral infection was clearly not the probability of a left and a right side infection, but rather was closer to the probability of a left or a right side infection.

All size classes of infected fish had immature as well as mature plasmodia, but the relative proportions of immature and mature plasmodia varied with size class and collection date. The presence of both mature and immature plasmodia on the same gill bar indicated an existing infection but did not preclude the fish's susceptibility to subsequent infections. Although these data are not tabulated, 37 individual fish of the total infected subpopulation for 1976 were observed with both mature and immature plasmodia, and frequently both immature and mature plasmodia occurred on the same gill bar. When relative proportions of mature and immature plasmodia were expressed as a $\mathrm{m} / \mathrm{i}$ ratio (Fig. 6), the lowest value (i.e., highest proportion of immature plasmodia) occurred in 4.0 to $4.5 \mathrm{~cm}$ fish. However, the presence of immature plasmodia in 7.5 to $8.0 \mathrm{~cm}$ fish showed mature fish to be nearly as susceptible to infection as 3.5 to $6.0 \mathrm{~cm}$ fish, which were likely the oldest young of the year.

Plasmodia, both mature and immature, were somewhat unevenly distributed between sexes; the total sample male : female ratio was 1.00 : 1.62 while the male : female fish ratio in the infected subpopulation was $1.00: 1.37$. Thus, female fish were predominant in the total sample but less so in the infected portion of that sample.

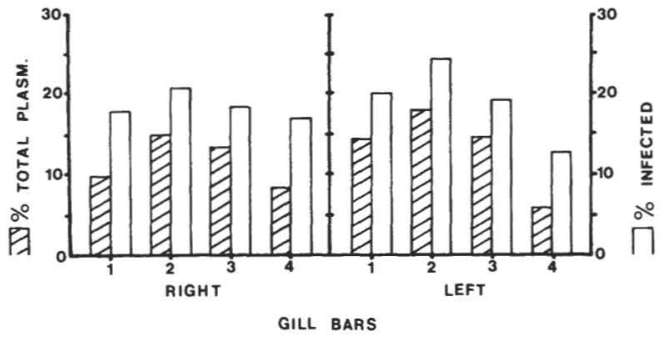

Figure 5. Percent frequency distribution of $M$. funduli plasmodia on individual $F$. kansae gill bars and percent of total $F$. kansae gill bars infected. Open bars-Percent of total gill bars infected. Cross-hatched bars-Percent of total observed plasmodia per gill bar.

\section{DISCUSSION}

The major contribution of this paper is the demonstration that a protozoan parasite population, in the form of plasmodia, is overdispersed within a host population so that the distribution can be described by the negative binomial curve. In the case of $M$. funduli plasmodia within the $F$. kansae population, the parasite distribution is similar to that described for many helminth populations (Crofton, 1971; Pennycuick, 1971; Thomas, 1964). Although the detailed life cycle of $M$. funduli, as well as that of virtually every other myxosporidan species, is unknown, published theoretical cycles suggest that a single plasmodium is the result of a single fish-spore encounter (Olsen, 1967). If this is true, then unlike the case with many protozoan parasites, the host-para-

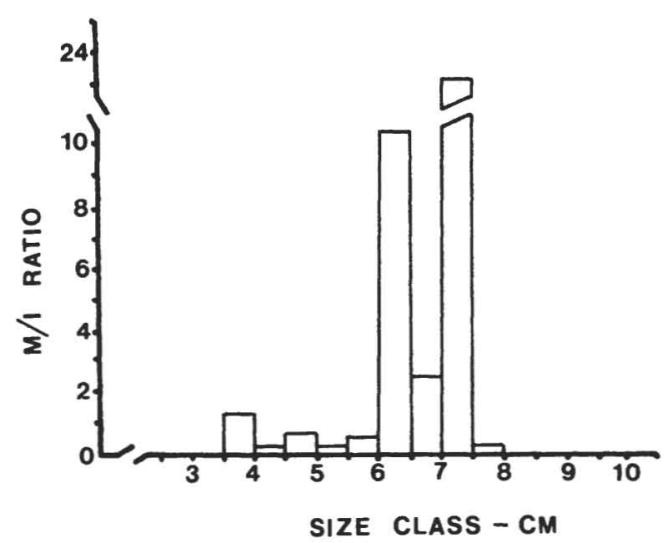

FIgURE 6. Size class distribution of mature/immature plasmodium ratios of infected fish subpopulation, summer, 1976. 
site encounter is not obscured by subsequent parasite reproduction in the host. Parasite reproduction does occur in that the plasmodium becomes multinucleate and many spores are eventually produced from the plasmodium, but this reproduction is structurally compartmentalized within the plasmodial wall (Current and Janovy, 1976a, b, c) unless future studies demonstrate "budding" by $M$. funduli plasmodia. The $M$. funduli-F. kansae relationship should thus allow application of helminth population dynamics techniques to analysis of a protozoan system. The relationship should allow study of the dynamics of the fish-spore encounter, and eventually allow detailed demographic/ epizootic research to be done on a system closely related to those causing major economic losses to the fish farming industry and major health problems in natural fish populations (Meyer, 1970; Sanders et al., 1970).

A second contribution of this study is the demonstration that demographic characteristics of the infected fish subpopulation are virtually identical to those of the whole fish population (Figs. 2A, B, 3). Thus young of the year at $3.5 \mathrm{~cm}$ carry patent infections, an observation which strongly suggests a prepatent period of 2 months or less for $M$. funduli. The source of infective spores for these young of the year is critical to our understanding of regulation of this parasite population; however, that knowledge must await discovery of the complete and detailed life cycle. Infective spores may be a year old, they may be those released by current year adults, or they may be those already processed by some unknown intermediate or transport host. Thus for this host-parasite system, the most pressing need is for knowledge of spore biology, and that knowledge can be gained only when a defined and predictable technique for assaying spore viability and infectivity is developed. It is hoped that Fundulus kansae will be useful as a laboratory host and can be added to the list of species appropriate for experimental studies of myxosporidan life cycles.

The presence of both mature and immature plasmodia on individual fish suggests that an existing infection does not preclude subsequent infection in this system. If this observation can be shown to be also true of a variety of myxosporidan infections, then one might conclude that these parasites do not elicit significant immune responses, at least when they occur in the gill tissues.

The most unusual observation in the present study is the proportion of unilateral vs. bilateral infections. The probability of a bilateral infection should be the probability of a right and left infection, but this is evidently not the case. Possible explanation may lie in gill chamber irrigation of the fish if infection is direct or in the gill blood supply patterns if infection is via the digestive tract.

This is the first report of $M$. funduli from $F$. kansae. M. funduli has also been reported from F. heteroclitus, F. majalis, and F. diaphanus by Hoffman et al. (1965).

\section{ACKNOWLEDGMENTS}

The authors would like to acknowledge the assistance of Mr. M. McCarty and Mr. R. Goble in collecting and analyzing 1975 data and Dr. B. B. Nickol, Director of CPBS, for making station facilities available for the research. The studies were supported in part by a grant from the UN-L Research Council.

\section{LITERATURE CITED}

Bentall, R. (Preparator) 1975. Hydrology, Nebraska Mid-State Division, Pick-Sloan Missouri Basin Program, and Associated Areas. UN-L Conservation and Survey Division, Lincoln, $256 \mathrm{p}$.

Burss, C. I. 1953. Fitting the negative binomial distribution to biological data. Biometrics 9: 176-196.

Crofton, H. D. 1971. A quantitative approach to parasitism, Parasitology 62: 179-193.

Current, W. L., AND J. Janovy, Jr. 1976a. Ultrastructure of interlamellar Henneguya exilis in the channel catfish. J Parasitol 62: 975981.

, AND $\longrightarrow$ 1976b. Sporogenesis in Henneguya exilis infecting channel catfish. Protistologica (in press).

— AND —. 1976c. Comparative ultrastructure of interlamellar and intralamellar Henneguya exilis in the channel catfish. J Protozool (in press).

Hoffman, G., and G. L. Hoffman, Jr. 1972. Studies on the control of whirling disease (Myxosoma cerebralis). I. The effects of chemicals on spores in vitro, and of calcium oxide as a disinfectant in simulated ponds. $\mathrm{J}$ Wildl Dis 8 : 49-53.

, AND R. E. PUTz. 1969. Host susceptibility 
and the effect of aging, freezing, heat and chemicals on spores of Myxosoma cerebralis. Prog Fish Cult 31 : 35-38.

, AND - 1971. Effects of freezing and aging on the spores of Myxosoma cerebralis, the causative agent of salmonid whirling disease. Prog Fish Cult 33: 95-98.

and C. E. Dunbar. 1965

Studies of Myxosoma cartilaginis n. sp. (Protozoa: Myxosporidae) of centrarchid fish and a synopsis of the Myxosoma of North American freshwater fishes. J Protozool 12: 319-332.

Meyer, K. P. 1970. Seasonal fluctuations in the incidence of disease on fish farms. In $\mathrm{A}$ Symposium on Diseases of Fishes and Shellfishes. American Fisheries Society, Washington, D.C., p. 21-29.

Minckley, C. O., and H. E. KlaAssen. 1969. Life history of the plains killifish, Fundulus kansae (Garman), in the Smoky Hill River, Kansas. Trans Am Fish Soc 98: 460-465.

Olsen, O. W. 1967. Animal Parasites. Burgess Publishing Co., Minneapolis, 431 p.

Pennycuick, L. 1971. Frequency distributions of parasites in a population of three-spined sticklebacks, Gasterosteus aculeatus L., with particular reference to the negative binomial distribution. Parasitology 63: 389-406.

Sanders, J. E., J. L. Fryer, and R. W. Gould. 1970. Occurrence of the myxosporidan parasite Ceratomyxa shasti, in salmonid fish from the Columbia River basin and Oregon coastal streams. In A Symposium on Diseases of Fishes and Shellfishes. American Fisheries Society, Washington, D.C., p. 133-141.

Thomas, J. D. 1964. Studies on populations of helminth parasites in brown trout (Salmo trutta L.). J Anim Ecol 33: 83-95. 